\title{
Specific Detection of Burkholderia plantarii and B. glumae by PCR Using Primers Selected from the $16 \mathrm{~S}-23 \mathrm{~S}$ rDNA Spacer Regions
}

\author{
Toru TAKEUCHI*, Hiroyuki SAWADA**, Fumihiko SUZUKI** \\ and Izumi MATSUDA**
}

\begin{abstract}
Specific polymerase chain reaction (PCR) primers targeting genomic DNA were selected for rapid, sensitive and specific detection of Burkholderia plantarii and $B$. glumae, the causal agents of bacterial seedling blight of rice and bacterial seedling rot of rice, respectively. The complete sequences of the spacer region between the $16 \mathrm{~S}$ and $23 \mathrm{~S}$ rRNA genes of $B$. plantarii, B. glumae, B. gladioli, B. cepacia, $B$. caryophylli, $B$. andropogonis, $B$. solanacearum and Pseudomonas corrugata, were determined. Among strains of $B$. plantarii from diverse geographical regions in Japan, the degree of sequence similarity was more than $93 \%$. All strains of $B$. glumae isolated in diverse geographical regions in Japan had the same sequence. The degree of similarity among the strains of Burkhorderia spp. ranged from $60 \%$ to $90 \%$, but less than $59 \%$ between strains of Burkholderia spp. and strains of $P$. corrugata, $P$. fuorescens and Escherichia coli. These results suggest that the sequences are conserved within species, but are variable between species. Since strains of $B$. plantarii, B. glumae and B. gladioli exhibited a relatively high degree of sequence similarity (81-90\%) to each other, we designed species-specific primers from the sequence of the regions that were conserved within species, but not between species. In PCR with PL-12f $\left(5^{\prime}\right.$ AGCCAGTCAGAGGATAAGTC-3') and PL-11r (5'-CAATTGAGCCGAACATTTAAG-3') primers, an approximately 180 -bp fragment was amplified in all 45 strains of $B$. plantarii. No PCR products were obtained from other bacteria tested. Primers GL-13f ( $5^{\prime}$-ACACGGAACACCTGGGTA-3') and GL-14r $\left(5^{\prime}\right.$-TCGCTCTCCCGAAGAGAT $\left.\cdot 3^{\prime}\right)$ amplified an approximately $400 \cdot \mathrm{bp}$ fragment in all 20 isolates of $B$. glumae, whereas no PCR products were obtained from other species of bacteria. Using the specific primers designed in this study, the PCR method can detect and identify $B$. glumae and $B$. plantarii in rice samples within $6 \mathrm{hr}$.
\end{abstract}

(Received February 3, 1997 ; Accepted September 10, 1997)

Key words : PCR, specific detection, spacer region, Burkholderia plantarii, Burkholderia glumae.

\section{INTRODUCTION}

Burkholderia plantarii (Azegami, Nishiyama, Watanabe, Kadota, Ohuchi and Fukazawa 1987) Urakami, Ito-Yoshida, Araki, Kijima, Suzuki and Komagata $1994^{18)}$ and B. glumae (Kurita and Tabei 1967) Urakami, Ito-Yoshida, Araki, Kijima, Suzuki and Komagata $1994^{18)}$ cause bacterial seedling blight of rice and bacterial seedling rot of rice, respectively, in Japan ${ }^{2,177}$. They are seed-borne pathogens and cause serious damage of rice seedlings in nursery boxes, especially in the northern part of Japan. Seedlings infected with these pathogens cannot be used for transplanting.

Selective media for both $B$. plantarii ${ }^{1,13)}$ and $B$. gluma $^{15}$ ) have been reported, however, $B$. glumae can also be detected and identified using a serological method $^{9)}$ or a specific DNA probe ${ }^{16}$. In contrast, no specific probe has yet been developed for $B$. plantarii which has several serological groups ${ }^{7,111}$.

The polymerase chain reaction (PCR) has been used to detect plant pathogenic bacteria, because it is a more rapid, sensitive and specific method than conventional ones used for detecting pathogen $\mathrm{s}^{10,20)}$. The objective of this study was to select and apply PCR primers, targeting the spacer region between $16 \mathrm{~S}$ and $23 \mathrm{~S}$ rRNA genes of $B$. plantarii and B. glumae, for specific detection of these pathogens in rice samples.

\section{MATERIALS AND METHODS}

Bacterial strains Bacterial cultures used for DNA sequencing consisted of eight strains of Burkholderia plantarii, six strains of $B$. glumae, five strains of $B$.

\footnotetext{
* Hokkaido Central Agricultural Experiment Station, Naganuma, Yubari-gun, Hokkaido 069-13, Japan 北海道立中央農
} 業試験場

** National Institute of Agro-Environmental Science, Tsukuba 305, Japan＼cjkstart農業環境技術研究所 
Table 1. Bacterial strains used

\begin{tabular}{|c|c|c|c|}
\hline $\begin{array}{c}\text { Bacterium } \\
\text { (No. of strains) }\end{array}$ & Strain & $\begin{array}{c}\text { Geographic } \\
\text { origin }\end{array}$ & Host plants \\
\hline \multirow[t]{23}{*}{ Burkholderia plantarii (45) } & MAFF $311032^{*}$ & Hokkaido & Rice \\
\hline & Yamagata-9* & Yamagata & Rice \\
\hline & Akita-1* & Akita & Rice \\
\hline & MAFF $311029^{*}$ & Hokkaido & Rice \\
\hline & MAFF $311031^{*}$ & Hokkaido & Rice \\
\hline & MAFF $301723^{\text {T * }}$ & Chiba & Rice \\
\hline & $\mathrm{HZ}^{*}$ & Oita & Rice \\
\hline & MAFF $302485^{*}$ & Miyagi & Rice \\
\hline & IW2-11, IW3-11, IW5-11, & Hokkaido & Rice \\
\hline & BB1-11, BB3-12, ST1-11 & & \\
\hline & ST2-31, TK2-11, TK-1-11A & & \\
\hline & IK0-11, IK2-11, IK4-11, & & \\
\hline & YN1-11, YN2-21, KW0-11 & & \\
\hline & KM1-12, UK1-11, TG1-11 & & \\
\hline & HK1-21, HT1-11, NG1-11, & & \\
\hline & OT2-11, ST1-11B, IW1-11, & & \\
\hline & TM1-11, MT1-11, & & \\
\hline & KY92431-1, TS92421-1, & & \\
\hline & $\begin{array}{c}\text { NG92411-2, Tsukigata-94 } \\
\text { MAFF } 302387, \text { MAFF } 302412\end{array}$ & Chiba & Rice \\
\hline & $\begin{array}{l}\text { MAFF 302387, MAFF } 302412 \\
\text { MR8521, MR8801 }\end{array}$ & $\begin{array}{l}\text { Chiba } \\
\text { Miyagi }\end{array}$ & $\begin{array}{l}\text { Rice } \\
\text { Rice }\end{array}$ \\
\hline & $\begin{array}{l}\text { MR8521, MR8801 } \\
\text { YR8803 }\end{array}$ & Miyagi & $\begin{array}{l}\text { Rice } \\
\text { Rice }\end{array}$ \\
\hline & $\begin{array}{l}\text { YR8803 } \\
\text { IR8901 }\end{array}$ & & Rice \\
\hline & IR8901 & Iwate & Rice \\
\hline \multirow[t]{16}{*}{ B. glumae (20) } & MAFF $311028^{*}$ & Hokkaido & Rice \\
\hline & MAFF $301169^{\top *}$ & Ehime & Rice \\
\hline & MAFF $301386^{*}$ & Fukuoka & Rice \\
\hline & MAFF $301388^{*}$ & Yamagata & Rice \\
\hline & MAFF $301441^{*}$ & Hiroshima & Rice \\
\hline & MAFF $301682^{*}$ & Ibaraki & Rice \\
\hline & MAFF 311026, MAFF 311027 & Hokkaido & Rice \\
\hline & MAFF 301171 & Kagawa & Rice \\
\hline & Ku8123, 8223 & Fukuoka & Rice \\
\hline & MAFF 301387 & Kumamoto & Rice \\
\hline & MAFF 301389 & Akita & Rice \\
\hline & MAFF 301442 & Hiroshima & Rice \\
\hline & Miyagi-4 & Miyagi & Rice \\
\hline & MR8740, MR8705, MR8781 & Miyagi & Rice \\
\hline & IR8912 & Iwate & Rice \\
\hline & 7601 & Okayama & Rice \\
\hline \multirow[t]{3}{*}{ B. gladioli pv. gladioli (3) } & MAFF $311021^{\mathrm{T}}\left(\operatorname{ICMP} 3950^{\top}\right)^{*}$ & USA & Gladiolus \\
\hline & MAFF $301066^{*}$ & Chiba & Freesia \\
\hline & MAFF $301588^{*}$ & Tochigi & Cymbidium \\
\hline B. gladioli pv. alliicola (1) & MAFF 311022 (ICMP 2804)* & USA & Onion \\
\hline \multirow[t]{2}{*}{ B. gladioli (3) } & $8726^{*}$ & Japan & Rice \\
\hline & 8729,8789 & Japan & Rice \\
\hline B. cepacia (1) & MAFF $311023^{\mathrm{T}}\left(\text { ICMP } 5796^{\mathrm{T}}\right)^{*}$ & USA & Onion \\
\hline B. caryophylli (1) & MAFF $\left.311024^{\mathrm{T}}(\mathrm{ICMP512})^{\mathrm{T}}\right)^{*}$ & USA & Carnation \\
\hline B. andropogonis (1) & MAFF $302151^{\mathrm{T}}\left(\text { ATCC } 23061^{\mathrm{T}}\right)^{*}$ & USA & Sorghum \\
\hline B. solanacearum (1) & MAFF $302154^{\mathrm{T}}\left(\text { ATCC } 11696^{\mathrm{T}}\right)^{*}$ & USA & Tomato \\
\hline Pseudomonas corrugata (1) & MAFF $302158^{\mathrm{T}}\left(\text { ATCC } 29736^{\mathrm{T}}\right)^{*}$ & UK & Tomato \\
\hline
\end{tabular}

*Strains used for DNA sequencing.

gladioli, and type strains of B. cepacia, B. caryophylli, $B$. andropogonis, $B$. solanacearum and Pseudomonas corrugata. In addition, 37 strains of $B$. plantarii, 14 strains of $B$. glumae and two strains of $B$. gladioli were used to test the specificity of PCR amplification (Table 1).
DNA extraction Bacteria were grown on $\mathrm{KB}$ agar or $\mathrm{PPGA}^{8}$. The DNA template for PCR was extracted from cells (approximately $10^{8} \mathrm{cfu} / \mathrm{ml}$ ) using the InstaGene DNA purification matrix (Bio-Rad Laboratories) according to the supplier's instructions. 
DNA sequencing The sequences of the spacer region between the $16 \mathrm{~S}$ and $23 \mathrm{~S}$ rRNA genes were determined by PCR by using the following method as described previously ${ }^{14}$. The primers used for amplification were designed on the basis of conservation of the rRNA sequences or PCR primers of Escherichia coli ${ }^{3,4}$, B. cepacia $^{6)}$ and Pseudomonas fuorescens ${ }^{5}$. The PCR primers contained the sequences of $\mathrm{Cy}$-5-labeled primers for cycle sequencing reactions. The following primers were used to amplify the $16 \mathrm{~S}-23 \mathrm{~S}$ rDNA spacer regions: B-01, 5'-CGCCAGGGTTTTCCCAGTCACGACGGGTGAAGTCGTAACAAGGTA-3', corresponding to positions 1487 to 1507 of $E$. coli $16 \mathrm{~S}$ rDNA $^{3)}$; and B-02 5'-TTTCACACAGGAAACAGCTATGACTGATCGCCAAGGCATCCACC $-3^{\prime}$, corresponding to positions 23 to 42 of $E$. coli $23 \mathrm{SDNA}^{4}$ (the underlined portions of the primers correspond to the sequences of $\mathrm{Cy}$-5-labeled primers). PCR amplification of the target sequence was performed in a $50-\mu 1$ (total volume) reaction mixture containing $50 \mathrm{mM} \mathrm{KCl}, 10 \mathrm{mM}$ Tris- $\mathrm{HCl}(\mathrm{pH} \mathrm{9.0),} 0.1 \%$ Triton X-100, $1.5 \mathrm{mM} \mathrm{MgCl}_{2}$, each deoxynucleoside triphosphate (dNTP) at a concentration of $200 \mu \mathrm{M}, 5 \mathrm{pmol}$ of each primer, $2.5 \mu \mathrm{l}$ of template and $2.5 \mathrm{U}$ of $\mathrm{Taq}$ polymerase (TOYOBO). PCR was performed with a model 480 DNA thermal cycler (Perkin-Elmer Cetus) by using the following protocol : initial denaturation at $95^{\circ} \mathrm{C}$ for $2.5 \mathrm{~min}$, followed by 35 cycles consisting of denaturation at $95^{\circ} \mathrm{C}$ for $1 \mathrm{~min}$, annealing at $55^{\circ} \mathrm{C}$ for $1 \mathrm{~min}$, extension at $72^{\circ} \mathrm{C}$ for $2 \mathrm{~min}$ and an additional extension step consisting of $72^{\circ} \mathrm{C}$ for $10 \mathrm{~min}$. The B-02 primer was biotinylated, and the biotinylated PCR products then immobilized on streptavidin-coated paramagnetic beads (Dynabeads M-280 strepvidin ; DYNAL). Single-stranded DNA templates were prepared by following the manufacturer's instructions. Both strands were then sequenced directly by cycle sequencing using ALFred autocycle sequencing kit (Pharmacia Biotech) and the following Cy-5-labeled primers : primer ALFred M13-40 (5'-CGCCAGGGTTT TCCCAGTCACGAC-3') and reverse primer ALFred M13 (5'-TTTCACACAGGAAACAGCTATGAC-3 ${ }^{\prime}$ ). The sequencing products were loaded onto a $6 \%$ polyacrylamide gel, and separation was monitored on-line with an ALFred DNA sequencer (Pharmacia Biotech).

Selection of PCR primers for specific amplification Sequence data of $16 \mathrm{~S}-23 \mathrm{~S}$ rDNA spacer regions for the strains were manually aligned. Optimal conditions for PCR were determined with a $20-\mu 1$ reaction volume containing $1 \times T a q$ buffer (supplied with Taq polymerase by Gibco-BRL), $200 \mu \mathrm{M}$ dNTPs, $2.5 \mathrm{mM}$ $\mathrm{MgCl}_{2}, 0.5 \mathrm{U}$ of $\mathrm{Taq}$ polymerase (Gibco-BRL), $1 \mu \mathrm{l}$ of DNA template, $0.2 \mu \mathrm{M}$ each primer and $0.5 \mu 1$ of $10 \%$ skim milk. PCR was performed with a thermal cycler (MJ Research) by using the following protocol: initial denaturation at $94^{\circ} \mathrm{C}$ for $2.5 \mathrm{~min}$, followed by 35 cycles consisting of denaturation at $94^{\circ} \mathrm{C}$ for $1 \mathrm{~min}$, annealing at $60^{\circ} \mathrm{C}$ for $1 \mathrm{~min}$, extension at $72^{\circ} \mathrm{C}$ for $2 \mathrm{~min}$ and an additional extension step at $72^{\circ} \mathrm{C}$ for $5 \mathrm{~min}$. PCR prod- ucts were resolved in a $2 \%$ agarose gel in TAE buffer and stained with ethidium bromide.

The lower limit of sensitivity for PCR amplification was determined by testing dilution series of pure cultures. Loopfuls of $B$. plantarii MAFF 311032 and $B$. glumae MAFF 311028 were suspended separately in $1 \mathrm{ml}$ of sterile distilled water and diluted in a 10 -fold series. The concentration of bacteria was determined by a standard plate-counting procedure on PPGA medium. One hundred $\mu 1$ of each dilution was held at $95^{\circ} \mathrm{C}$ for 8 min and centrifuged at $10,000 \mathrm{rpm}$ for $3 \mathrm{~min}$. The supernatant was then used for the PCR. The PCR reactions were run with the DNA extract of $B$. plantarii MAFF 311032 or $B$. glumae MAFF 311028 as positive controls and without DNA as a negative control.

PCR for detection of $B$. plantarii and B. glumae in rice seedlings Rice seedling samples were grown in nursery boxes from seed, which had been inoculated prior to sowing by dipping in a suspension of about $10^{8}$ cells per $\mathrm{ml}$ of inoculum ${ }^{12)}$. Severely and slightly diseased seedlings, as well as asymptomatic ones were sampled and tested for the PCR. Healthy seedlings from non-inoculated plants were used as controls.

Bacterial DNA was extracted from each seedling sample by the following method. A small piece (10-20 $\mathrm{mg}$ ) of a seedling base was ground in a mortar with 1.0 ml of a $0.85 \% \mathrm{NaCl}$ solution. The resulting suspension was then placed in a micro tube and centrifuged at $10,000 \mathrm{rpm}$ for $5 \mathrm{~min}$. The pellet was resuspended in 0.1 $\mathrm{ml}$ of sterile water, held at $95^{\circ} \mathrm{C}$ for $8 \mathrm{~min}$ and centrifuged at $10,000 \mathrm{rpm}$ for $3 \mathrm{~min}$. Five $\mu 1$ of this supernatant was used directly as a template for the PCR.

\section{RESULTS}

\section{Nucleotide sequences of the 16S-23S rDNA spacer regions}

The 16S-23S rDNA spacer regions of plant pathogenic Burkholderia species and Pseudomonas cormugata were determined. The sequence similarity matrix and length of the region are shown in Table 2. The spacer region of the examined strains was 496 to 660 base pairs in length and contained the genes for tRNA ${ }^{\text {ne }}$ and tRNA ${ }^{\text {Ala }}$.

The sequence data of the strains investigated in this study have been deposited in the GenBank, EMBL, and DDBJ under following accession numbers: D87079 for MAFF $301723^{\top}$, D87080 for MAFF $301169^{\mathrm{T}}$, D87081 for MAFF $311021^{\mathbf{T}}$ (ICMP $3950^{\mathrm{T}}$ ), D87082 for MAFF 311022 (ICMP 2804), D87083 for MAFF $311023^{\mathrm{T}}$ (ICMP 5796 ${ }^{\mathrm{T}}$ ), D87084 for MAFF $311024^{\mathrm{T}}$ (ICMP 512 ), D87085 for MAFF $302151^{\top} \quad\left(A T C C 23061^{\top}\right)$, D87086 for MAFF $302154^{\mathrm{T}}$ (ATCC $11696^{\mathrm{T}}$ ), and D87087 for MAFF $302158^{\mathrm{T}}$ (ATCC 29736T).

\section{Primer design and specificity}

The sequence alignment of the $16 \mathrm{~S}-23 \mathrm{~S}$ rDNA spacer regions of $B$. plantarii, $B$. glumae and $B$. gladioli is 
Table 2. Sequence similarity matrix of $16 \mathrm{~S}-23 \mathrm{~S}$ rDNA spacer region of plant pathogenic Burkholderia spp. and other bacteria

\begin{tabular}{|c|c|c|c|c|c|c|c|c|c|c|c|c|c|c|c|c|c|c|c|}
\hline & \multirow{2}{*}{$\begin{array}{c}\text { length } \\
\text { (bp) }\end{array}$} & \multicolumn{18}{|c|}{ \% Homology with: } \\
\hline & & $\mathrm{Pl}$ & $\mathrm{P} 2$ & P3 & $\mathrm{P} 4$ & $\mathrm{P} 5$ & P6 & $\mathrm{GL}$ & GG & $\mathrm{GF}$ & $\mathrm{GA}$ & $\mathrm{GC}$ & GR & $\mathrm{CE}$ & $\mathrm{CA}$ & AN & SO & PC & PF \\
\hline P1 & 569 & & & & & & & & & & & & & & & & & & \\
\hline P2 & 569 & 99.8 & & & & & & & & & & & & & & & & & \\
\hline P3 & 569 & 99.7 & 99.7 & & & & & & & & & & & & & & & & \\
\hline P4 & 557 & 94.2 & 94.1 & 93.9 & & & & & & & & & & & & & & & \\
\hline P5 & 557 & 94.2 & 94.1 & 93.9 & 99.8 & & & & & & & & & & & & & & \\
\hline P6 & 560 & 93.6 & 93.4 & 93.2 & 98.8 & 98.9 & & & & & & & & & & & & & \\
\hline GL & 560 & 89.6 & 89.4 & 88.3 & 88.5 & 88.5 & 89.4 & & & & & & & & & & & & \\
\hline GG & 548 & 88.3 & 88.1 & 88.3 & 88.5 & 88.5 & 88.2 & 88.5 & & & & & & & & & & & \\
\hline GF & 550 & 88.6 & 88.4 & 88.6 & 88.7 & 88.7 & 88.4 & 88.6 & 99.5 & & & & & & & & & & \\
\hline GA & 557 & 89.4 & 89.2 & 89.5 & 89.6 & 89.6 & 89.1 & 89.1 & 96.1 & 95.5 & & & & & & & & & \\
\hline GC & 558 & 89.4 & 89.2 & 89.5 & 90.0 & 90.0 & 89.5 & 89.5 & 96.4 & 96.2 & 99.3 & & & & & & & & \\
\hline GR & 596 & 81.8 & 81.7 & 81.9 & 81.9 & 81.9 & 81.5 & 81.4 & 89.8 & 89.6 & 88.8 & 88.3 & & & & & & & \\
\hline $\mathrm{CE}$ & 592 & 76.5 & 76.4 & 76.5 & 78.3 & 78.2 & 77.9 & 77.3 & 80.6 & 80.5 & 79.7 & 79.5 & 75.3 & & & & & & \\
\hline CA & 660 & 65.7 & 65.6 & 65.8 & 66.8 & 66.8 & 67.4 & 66.0 & 67.2 & 67.1 & 66.0 & 65.9 & 62.8 & 71.4 & & & & & \\
\hline AN & 624 & 66.9 & 67.1 & 66.9 & 66.4 & 66.4 & 67.3 & 67.1 & 67.5 & 68.0 & 67.5 & 67.7 & 64.5 & 69.5 & 66.7 & & & & \\
\hline SO & 497 & 66.5 & 66.5 & 67.0 & 67.2 & 67.2 & 66.5 & 68.1 & 69.1 & 68.8 & 67.8 & 67.5 & 64.1 & 64.0 & 60.5 & 62.0 & & & \\
\hline $\mathrm{PC}$ & 496 & 57.8 & 56.7 & 56.8 & 58.4 & 57.8 & 57.6 & 58.4 & 57.2 & 58.5 & 57.4 & 58.3 & 56.5 & 53.4 & 49.7 & 52.7 & 57.9 & & \\
\hline $\mathrm{PF}$ & 516 & 56.8 & 56.6 & 56.6 & 57.2 & 57.1 & 57.0 & 57.5 & 57.2 & 56.9 & 57.5 & 56.8 & 54.2 & 53.0 & 49.5 & 52.3 & 58.0 & 88.7 & \\
\hline $\mathrm{EC}$ & 437 & 51.7 & 51.7 & 51.7 & 53.2 & 53.4 & 53.0 & 53.2 & 53.2 & 52.7 & 52.6 & 52.0 & 49.3 & 51.0 & 47.4 & 48.5 & 55.7 & 58.5 & 58.2 \\
\hline
\end{tabular}

P1, Burkholderia plantarii MAFF 311032 and Yamagata-9; P2, B. plantarii Akita-1; P3, B. plantarii MAFF 311029 and MAFF 311031 ; P4, B. plantarii MAFF $301723^{\mathrm{T}}$; P5, B. plantarii HZ; P6, B. plantarii MAFF 301723 ; GL, B. glumae MAFF 311028 , MAFF $301169^{\top}$, MAFF 301386, MAFF 301388, MAFF 301441 and MAFF 301682 ; GG, B. gladioli pv. gladioli MAFF $311021^{\mathrm{T}}$; GF, B. gladioli pv. gladioli MAFF 301066 ; GC, B. gladioli pv. gladioli MAFF 311588 ; GA, B. gladioli pv. allicola MAFF 311022 ; GR, B. gladioli 8726 ; CE, B. cepacia MAFF $311023^{\mathrm{T}}$; CA, B. caryophylli MAFF $311024^{\mathrm{T}}$; AN, B. andropogonis MAFF $302151^{\mathrm{T}}$; SO, B. solanacearum MAFF $302154^{\mathrm{T}}$; PC, Pseudomonas corrugata MAFF $302158^{\mathrm{T}}$; PF, P. fluorescens Qp5 $5^{\mathrm{s}}$; EC, Escherichia coli ${ }^{19)}$

shown in Fig. 1. On the basis of the sequence data, two pairs of PCR primers, PL-12f (5'-AGCCAGTCAGAGGATAAGTC-3') and PL-11r (5'-CAATTGAGCCGAACATTTAAG-3') for $B$. plantarii and GL-13f (5'-ACACGG. AACACCTGGGTA-3') and GL-14r (5'-TCGCTCTCCCGAAGAGAT-3') for $B$. glumae, were selected for specific amplification.

In PCR with PL-12f and PL-11r primers, an approximately 180 -bp fragment was amplified in all 45 strains of $B$. plantarii used in this study. No PCR products were obtained from other bacteria tested, including $B$. glumae, B. gladioli, B. cepacia, B. caryophylli, $B$. andropogonis, $B$. solanacearum, and $P$. corrugata. Primers GL-13f and GL-14r amplified an approximately 400-bp fragment in all 20 strains of $B$. glumae tested. No PCR products were obtained from other bacterial species (Table 3 and Fig. 2). Detection sensitivity of PCR for each bacterial species with the described primer pairs was $10^{1}$ to $10^{2}$ cfu per PCR reaction (Fig. 3).

$P C R$ detection of $B$. plantarii and $B$. glumae in rice seedlings

PCR products were obtained using the specific primers in PCR reactions on rice seedling samples which were collected from plants infected with $B$. plantarii or $B$. glumae. Tissue samples from symptomless seedlings that had been inoculated with each of the pathogens also produced a PCR product. Healthy seedling samples from non-inoculated plants were negative in PCR detection (Fig. 4).

Fig. 1. Sequence alignment of the spacer region between $16 \mathrm{~S}$ and $23 \mathrm{~S}$ rRNA genes of Burkholderia plantarii, B. glumae and $B$. gladioli. The sequences are aligned with the sequence of $B$. plantarii MAFF 311032 and Yamagata-9. Only nucleotides that differ from those of $B$. plantarii MAFF 311032 and Yamagata-9 are shown; identical nucleotides are indicated by dots, and deletions are indicated by dashes. The $3^{\prime}$ end of $16 \mathrm{~S}$ rRNA gene and the $5^{\prime}$ end of the 23S rRNA gene are also shown. The location of two tRNA genes within the spacer region is also indicated. Abbreviations: P1, B. plantarii MAFF 311032 and Yamagata-9; P2, B. plantarii Akita-1; P3, B. plantarii MAFF 311029 and MAFF 311031 ; P4, B. plantarii MAFF 301723 ; P5, B. plantarii HZ; P6, B. plantarii MAFF 301723 ; GL, B. glumae MAFF 311028, MAFF 301169, MAFF 301386, MAFF 301388, MAFF 301441 and MAFF 301682 ; GG, $B$. gladioli pv. gladioli MAFF 311021 ; GF, B. gladioli pv. gladioli MAFF 301066 ; GC, B. gladioli pv. gladioli MAFF 311588 ; GA, B. gladioli pv. allicola MAFF 311022 ; GR, B. gladioli 8726 . The underlined regions are specific primer sites. 


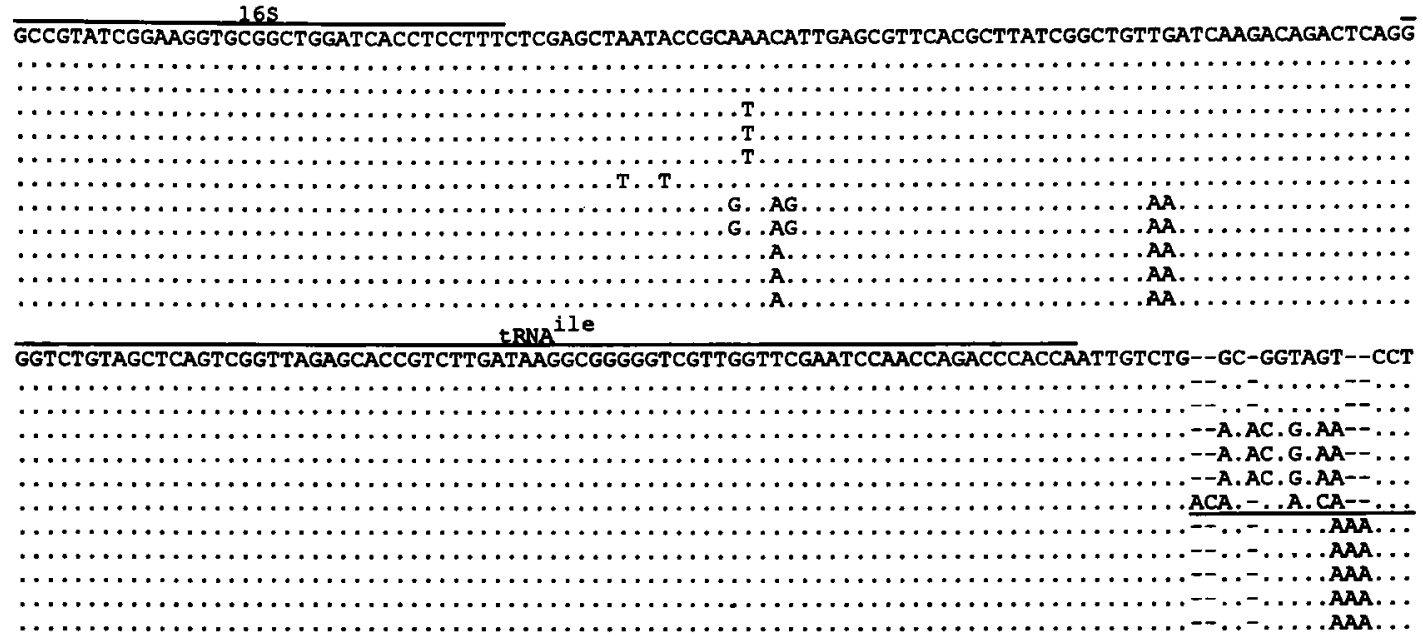

trNa ala
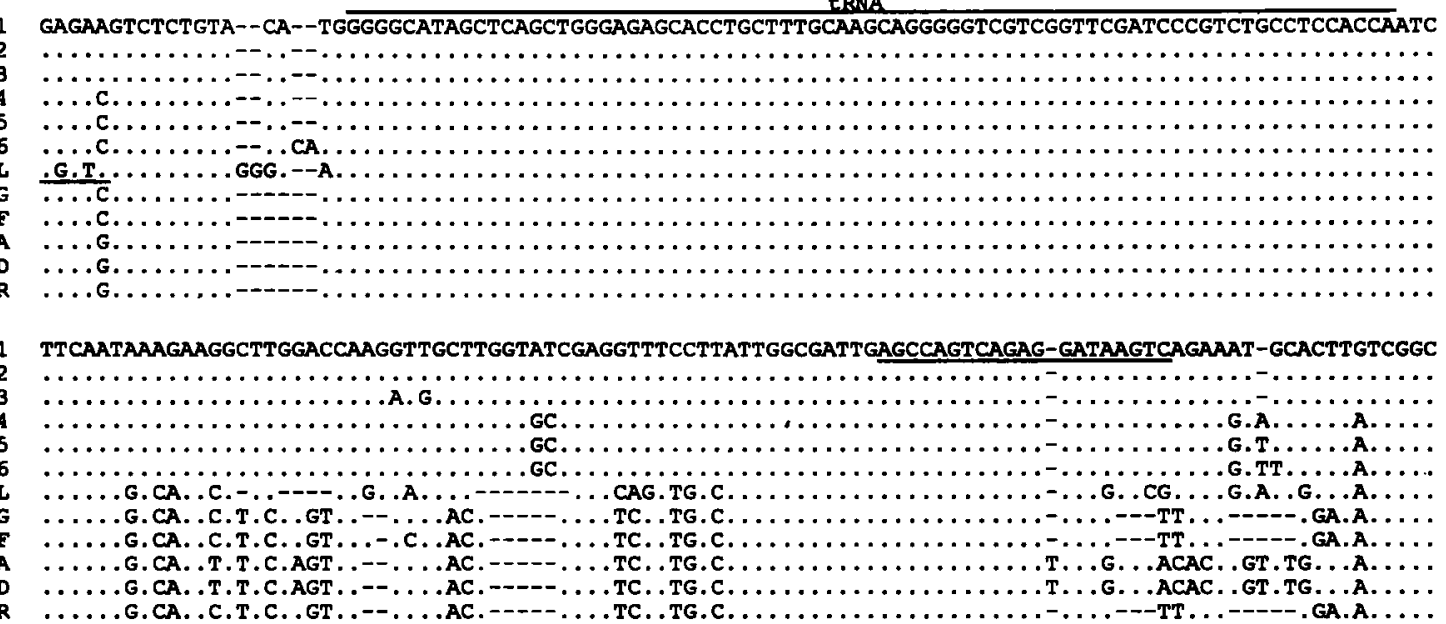

TGTCGTTCTTTAACAATCTAGAAGAAGTAGTAAAGTGGATAGCGGAAGCGTTATTTGAGATGGGGTGGAAATATCCGGGTTGGATTGTATCGATGT

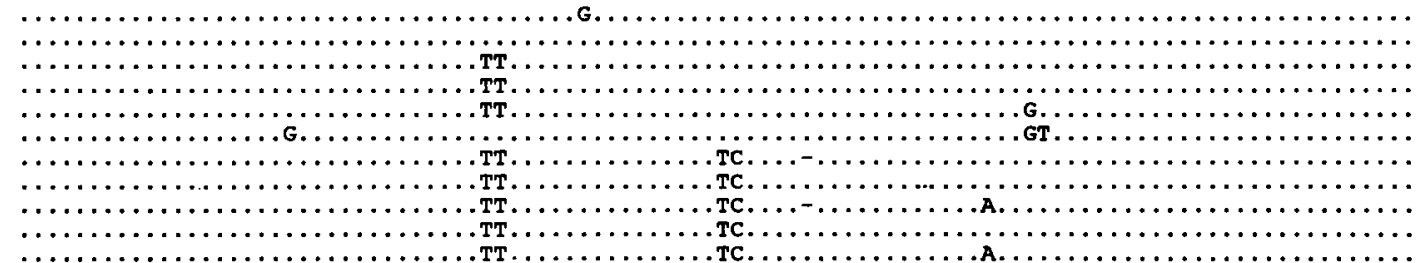

ATCTCAAGATGATTCG--AACTTAAACGTTCGG--

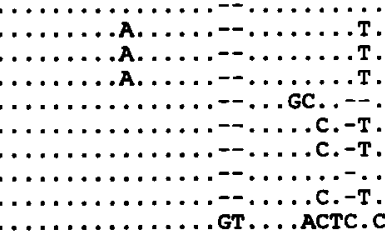

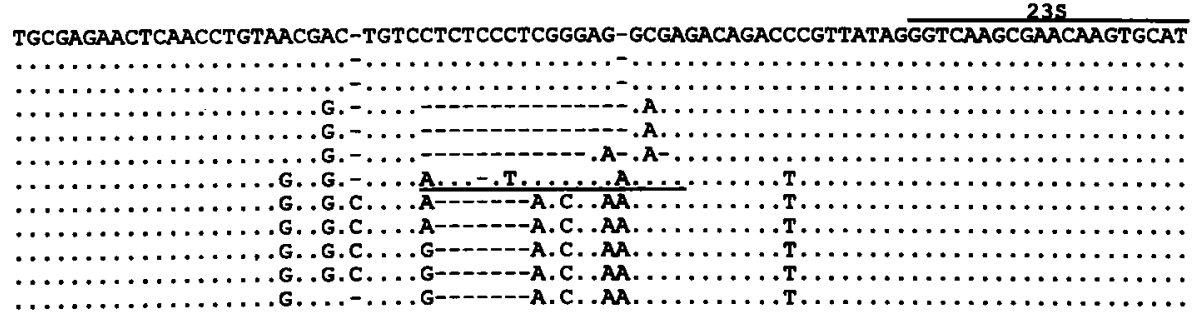

Fig. 1. 
Table 3. PCR amplification of bacterial strains using two pairs of primers

\begin{tabular}{lccc}
\hline \hline \multirow{2}{*}{ Bacterium } & No. of strains tested & \multicolumn{2}{c}{ No. of positive strains with primers: } \\
\cline { 3 - 4 } & 45 & PL-12f+PL-11r & GL-13f +GL-14r \\
\hline Burkholderia plantarii & 20 & 45 & 0 \\
B. glumae & 3 & 0 & 20 \\
B. gladioli pv. gladioli & 1 & 0 & 0 \\
B. gladioli pv. alliicola & 3 & 0 & 0 \\
B. gladioli & 1 & 0 & 0 \\
B. cepacia & 1 & 0 & 0 \\
B. caryophylli & 1 & 0 & 0 \\
B. andropogonis & 1 & 0 & 0 \\
B. solanacearum & 1 & 0 & 0 \\
Pseudomonas corrugata & & 0 & 0 \\
\hline
\end{tabular}

\section{$\begin{array}{llllllllllllllll}1 & 2 & 3 & 4 & 5 & 6 & 7 & 8 & 9 & 10 & 11 & 12 & 13 & 14 & 15\end{array}$}
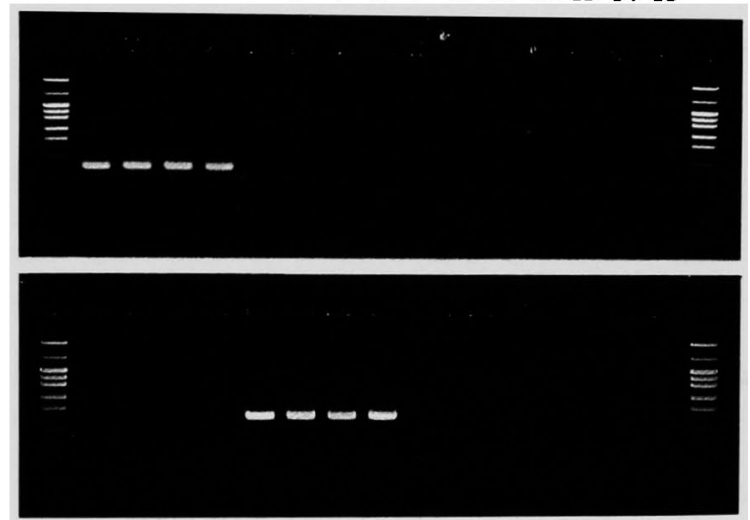

Fig. 2. Agarose gel electrophoresis of PCR products amplified using primers PL-12f and PL-11r (upper panel) and primers GL-13f and GL-14r (lower panel) from total DNA of Burkholderia strains. Lanes $1-4, B$. plantarii strains MAFF 311032, MAFF 301723, MAFF 302485 and MAFF 311031, respectively; lanes 5-8, $B$. glumae strains MAFF 311028, MAFF 301369, MAFF 301386 and MAFF 301388, respectively; lane 9, B. gladioli pv. gladioli MAFF 311021 ; lane $10, B$. gladioli pv. allicola MAFF 311022 ; lane $11, B$. gladioli 8726 ; lane $12, B$. cepacia MAFF 311023 ; lane $13, B$. caryophylli MAFF 311024 ; lane 14, B. andropogonis MAFF 302151 ; lane $15, B$. solanacearum MAFF 302154 . The left and right lanes (unmarked) in each panel contain molecular weight standards (pHY marker, Takara). The seventh and eighth fragments indicate 489 and $267 \mathrm{bp}$, respectively.

\section{DISCUSSION}

The complete sequences of the spacer regions between the $16 \mathrm{~S}$ and $23 \mathrm{~S}$ rRNA genes of plant pathogenic Burkholderia spp. were determined. Among strains of $B$. plantarii from diverse geographical regions in Japan, the degree of similarity was more than $93 \%$. All strains of $B$. glumae isolated in diverse geographical regions in Japan had the same sequence. These results are consis- $\begin{array}{llllllllllllllll}1 & 2 & 3 & 4 & 5 & 6 & 7 & 8 & 9 & 10 & 11 & 12 & 13 & 14 & 15 & 16\end{array}$

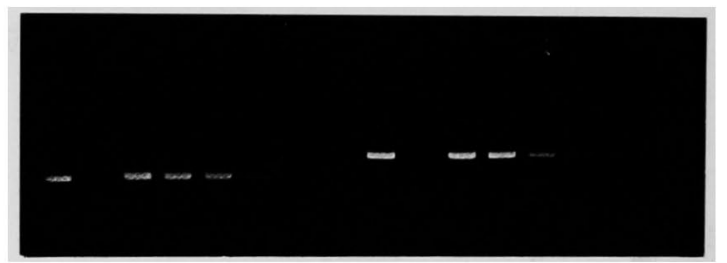

Fig. 3. Agarose gel electrophoresis of PCR products amplified using primers PL-12f and PL-11r (lanes 1-8) and primers GL-13f and GL-14r (lanes 9-16) from DNA extracts of dilution series of Burkholderia plantarii strain MAFF 311032 (lanes 3-8) and B. glumae strain MAFF 311028 (lanes 11-16). Number of bacteria added were as follows : $5 \times 10^{4}$ (lanes 3 and 11), $5 \times 10^{3}$ (lanes 4 and 12), $5 \times 10^{2}$ (lanes 5 and 13), $5 \times 10^{1}$ (lanes 6 and 14), 5 (lanes 7 and 15), 0 cfu per 20- $\mu$ l PCR reaction (lanes 8 and 16). Lanes 1 and 9 , positive controls (the DNA of $B$. plantarii MAFF 311032 and $B$. glumae MAFF 311028 , respectively); lanes 2 and 10 , negative controls (no DNA).

tent with the serological analysis of the pathogens reported previously ${ }^{7,9,11)}$, suggesting that $B$. plantarii contains more genetic variation than $B$. glumae.

The degree of similarity among strains of Burkholder. ia spp. ranged from $60 \%$ to $90 \%$, but less than $59 \%$ between strains of Burkholderia spp. and strains of $P$. corrugata, $P$. fuorescens and $E$. coli (Table 2). These results suggest that the sequences are conserved within species, but are variable between species. Therefore, sequence comparison in this region may be valuable for differentiating closely related species of bacteria.

Because strains of $B$. plantarii, $B$. glumae and $B$. gladioli exhibited a relatively high degree of sequence similarity $(81-90 \%)$ to each other, we designed the species-specific primers on the basis of the sequences of the regions that are conserved within species, but not between species (Fig. 1). The PCR method, using the specific primers designed, was found to be useful for rapid detection and identification of $B$. glumae and $B$. plantarii; the pathogens in rice samples can be identified 
$\begin{array}{llllllllllll}1 & 2 & 3 & 4 & 5 & 6 & 7 & 8 & 9 & 10 & 11 & 12\end{array}$

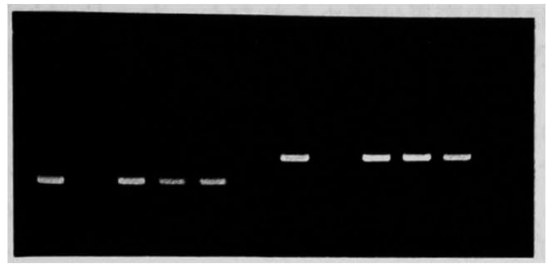

Fig. 4. Agarose gel electrophoresis of PCR products amplified using primers PL-12f and PL-11r (lanes 1-6) and primers GL-13f and GL-14r (lanes 7-12) from DNA extracts of rice seedling. Lanes 1 and 7, positive controls (the DNA of $B$. plantarii MAFF 311032 and $B$. glumae MAFF 311028 , respectively); lanes 2 and 8 , negative controls (no DNA); lanes 3-5 and 9-11, DNA extracts from rice seedling samples infected with $B$. plantarii or $B$. glumae, respectively; lanes 3 and 9 , severely diseased seedlings; lanes 4 and 10 , slightly diseased seedlings ; lanes 5 and 11 , asymptomatic inoculated seedlings ; lanes 6 and 12 , healthy seedlings from non-inoculated plants.

within $6 \mathrm{hr}$. Sensitivity of the PCR for these pathogens was almost the same as that for other bacteria reported ${ }^{10,20}$. In addition, the PCR detection of these two pathogens can be performed in the same set of experimental condition, including thermalcycler program. Since these pathogens are seed-borne, a method to detect them from seeds by PCR should be established in the future study.

The degree of similarity among strains of $B$. gladioli, including different pathovars and strains from diverse origins, was more than $88 \%$, indicating that this species consists of a heterogeneous group of strains. Therefore, no species-specific primer could be designed from the sequences of this region for $B$. gladioli.

We thank Dr. K. Nishiyama of the National Institute of Agro-Environmental Science for allowing us to use bacterial isolates from the MAFF gene bank and Dr. K. Azegami of the Kyushu National Agricultural Experiment Station for providing bacterial isolates.

\section{Literature cited}

1. Azegami, K., Nishiyama, K. and Kato, H. (1987). A selective medium and detection of Pseudomonas plantarii. Ann. Phytopathol. Soc. Jpn. 53: 70 (Abstr. in Japanese).

2. Azegami, K., Nishiyama, K., Watanabe, Y., Kadota, I., Ohuchi, A. and Fukazawa, C. (1987). Pseudomonas plantarii sp. nov., the causal agent of rice seedling blight. Int. J. Syst. Bacteriol. 37 : 144-152.

3. Brosius, J., Dull, T.J., Sleeter, D.D. and Noller, H.F. (1981). Gene organization and primary structure of a ribosomal RNA operon from Escherichia coli. J. Mol. Biol. 148 : 107-127.

4. Brosius, J., Palmer, M.L., Kennedy, P.J. and Noller, H.F.
(1978). Complete nucleotide sequence of a $16 \mathrm{~S}$ ribosomal RNA gene from Escherichia coli. Proc. Natl. Acad. Sci. USA 75 : 4801-4805.

5. Gill, S., Belles-Isles, J., Brown, G., Gagne, S., Lemieux, C., Mercier, J. and Dion, P. (1994). Identification of variability of ribosomal DNA spacer from Pseudomonas soil isolates. Can. J. Microbiol. $40: 541-547$.

6. Hopfl, P., Ludwig, W., Schleifer, K.H. and Larsen, N. (1989). The 23S ribosomal RNA higher-order structure of Pseudomonas cepacia and other prokaryotes. Eur. J. Biochem. 185 : 355-364.

7. Katoh, T., Osada, S., Nakaminami, H., Azegami, K. and Nishiyama, K. (1991). Bacterial strains from the rice seedlings showing chlorosis on their leaves in Yamagata, Miyagi, and Iwate prefectures and identification of Pseudomonas plantarii by serological method. Ann. Phytopathol. Soc. Jpn. 57 : 437-438 (Abstr. in Japanese).

8. Nishiyama, K. (1978). Rapid identification method for plant pathogenic bacteria. Plant Prot. 32 : 283-288 (in Japanese).

9. Matsuda, I. (1990). Rapid detection of Pseudomonas glumae. Plant Prot. 44 : 461-464 (in Japanese).

10. Maes, M., Garbeva, P. and Kamoen, O. (1996). Recognition and detection in seed of the Xanthmonas pathogens that cause cereal leaf streak using rDNA spacer sequences and polymerase chain reaction. Phytopathology $86: 63-69$.

11. Sato, Y., Takeuchi, T., Sawada, H., Suzuki, F. and Matsuda, I. (1996). Analysis of diversity of Pseudomonas plantarii by antisera and $16 \mathrm{~S}-23 \mathrm{~S}$ spacer. Ann. Phytopathol. Soc. Jpn. 62 : 305 (Abstr. in Japanese).

12. Takeuchi, T. (1994). A method for testing the effect of seed disinfection for bacterial seedling blight of rice. Ann. Rept. Plant Prot. North Japan 45: 21-26 (in Japanese).

13. Takeuchi, T. (1995). Detection and enumeration of Pseudomonas plantarii by selective medium. Ann. Phytopathol. Soc. Jpn. 61 : 650 (Abstr. in Japanese).

14. Takeuchi, T., Sawada, H., Tanaka, F. and Matsuda, I. (1996). Phylogenetic analysis of Streptomyces spp. causing potato scab based on $16 \mathrm{~S}$ rRNA sequences. Int. J. Syst. Bacteriol. $46:$ : 476-479.

15. Tsushima, S., Wakimoto, S. and Mogi, S. (1986). Selective medium for detecting Pseudomonas glumae Kurita et Tabei, the causal bacterium of grain rot of rice. Ann. Phytopathol. Soc. Jpn. 52 : 253-259 (in Japanese).

16. Tsushima, S., Narimatsu, C., Mizuno, A. and Kimura, R. (1994). Cloned DNA probes for detection of Pseudomonas glumae causing bacterial grain rot of rice. Ann. Phytopathol. Soc. Jpn. $60: 576-584$.

17. Uematsu, T., Yoshimura, D., Nishiyama, K., Ibaragi, T. and Fujii, H. (1976). Pathogenic bacterium causing seedling rot of rice. Ann. Phytopathol. Soc. Jpn. 42 : 464471 (in Japanese).

18. Urakami, T., Ito-Yoshida, C., Araki, H., Kijima, T., Suzuki, K. and Komagata, K. (1994). Transfer of Pseudomonas plantarii and Pseudomonas glumae to Burkholderia as Burkholderia spp. and description of Burkholderia vandii sp. nov. Int. J. Syst. Bacteriol. 44 : 235-245.

19. Young, R.A., Macklis, R. and Steiz, J.A. (1979). 
Sequence of the $16 \mathrm{~S}-23 \mathrm{~S}$ spacer region in two ribosomal RNA operons of Escherichia coli. J. Biol. Chem. 254: 3264-3271.

20. Xiang, L. and De Boer, S.H. (1995). Selection and polymerase chain reaction primers from an RNA intergenic spacer region for specific detection of Clavibacter michiganensis subsp. sepedonicus. Phytopathology 85 : 837-842.

\section{和 文 摘 要}

竹内 徹・澤田宏之・鈴木文彦・松田 泉: 16S-23S リボゾー ムDNA スペーサー領域の塩基配列を利用した Burkholderia plantarii およびB. glumae の特異的検出

イネ苗立枯細菌病菌 Burkholderia plantarii およびイネもみ 枯細菌病菌 B. glumae に対して, 特異的な PCR を利用した迅 速で高感度な特異的検出法を開発した。B. plantarii, B. glumae, $B$. gladioli, $B$. cepacia, $B$. caryophylli, $B$. andropogonis, $B$. solanacearum および Pseudomonas corrugata について, 16S お よび 23Sリボソーム RNA 遺伝子間に存在するスペーサー領域

の全塩基配列を比較解析した。地理的由来の異なる菌株におい
て同種内では, $B$. plantarii では 93\%以上の相同性を示し, $B$. glumae では種内変異は認められなかった。Burkholderia 属紐 菌の種間では 60〜90\%の相同性を, Burkholderia 属細菌とP. corrugata, P. fluorescens または Escherichia coli との間では $59 \%$ 以下の相同性を,それぞれ示した。以上の結果から, 本領域 は同種内では保存性が高く, 異種間では変異が大きいことが明 らかとなった。B. plantarii, B. glumae およびB. gladioli は互 いに比較的高い相同性 $(81 \sim 90 \%)$ を示したことから，これら 3 種の塩基配列を比較して, 種内で保存性が高く,かつ種間で変異 性の高い配列から種特異的なプライマーを設計した。プライマ - PL-12f (5'-AGCCAGTCAGAGGATAAGTC-3') と PL-11r (5'-CAATTGAGCCGAACATTTAAG-3')による PCR では, B. plantarii 供試 45 菌株すべてから約 $180 \mathrm{bp} の \mathrm{DNA}$ 断片の 増幅が認められたが, 他の細菌では認められなかった。プライマ - GL-13f (5'-ACACGGAACACCTGGGTA-3') 扔よびGL-14r (5'-TCGCTCTCCCGAAGAGAT-3') によるPCRでは, $B$. glumae 供試 20 菌株すへてから約 $400 \mathrm{bp}$ の DNA 断片の増幅 が認められたが, 他の細菌では認められなかった。また，特異プ ライマーを利用した PCRによって，それぞれの病原細菌が感染 したイネ苗から両菌を 6 時間以内で検出でき, 本法がイネ組織 内に括ける両菌の迅速検出に有効であることが示された。 